\title{
Прецедентні імена в індивідуальному лексиконі білінгва
}

\author{
О. А. Гапченко
}

Київський національний університет імені Тараса Шевченка, Київ, Україна

Corresponding author. E-mail: lengapchenko@gmail.com

Paper received 30.03.19; Accepted for publication 10.04.19.

https://doi.org/10.31174/SEND-Ph2019-195VII59-03

Анотація. Стаття присвячена дослідженню статусу прецедентних феноменів в індивідуальному лексиконі двомовної особистості. Прецедентні імена розглядаються як мовні знаки та як елементи когнітивної бази. Аналізуються чинники, що визначають специфіку зберігання і функціонування одиниць прецедентного типу в структурах індивідуального лексикону білінгвальної особистості, вивчаються факти впливу індивідуального природного і комбінованого білінгвізму на ці процеси.

Ключові слова: мовна особистість, прецедентний феномен, внутрішній лексикон, етнолінгвокультурна свідомість.

Вступ. Різні лінгво-культурні спільноти мають різні когнітивні бази, що пов'язано зі специфікою членування світу. Кожен білінгв, як мовна особистість, виступає як: 1) носій властивих тільки йому рис, ознак, знань і уявлень; 2) член певних соціальних груп (сім'я, професія, конфесія, політична орієнтація тощо); 3) представник певної національно-культурної спільноти; 4) представник людства. Когнітивна база, «з одного боку, є результатом дії специфічних для кожної мовної спільноти моделей сприйняття й обробки інформації, а 3 другого зберігає, структурує й визначає ці моделі, створює можливості для їх міжпоколінної трансляції, яка зумовлює, своєю чергою, мовну і культурну єдність членів певної спільноти» $[3,99]$. Серед основних складових когнітивної бази є прецедентні феномени: у когнітивній базі зберігається сам вербальний феномен (ім'я або висловлювання) і те, що за ним стоїть і що робить його прецедентним, тобто сукупність диференційних ознак і атрибутів (прецедентні імена) і сукупність значень-смислів (прецедентні висловлювання) [5, 79].

Огляд публікацій за темою. Прецедентність і пов'язані з нею явища останнім часом активно досліджуються в різних галузях сучасної лінгвістики. Явище прецедентності ставало об'єктом уваги таких лінгвістів, як Д. Б. Багаєва, В. О. Вуколова, Д. Б. Гудков, I. В. Захаренко, О. А. Земська, I. А. Казимірова, Ю. М. Караулов, В. Г. Костомаров, В. В. Красних, К. С. Серажим, Г.Г. Слишкін, Ю. О. Сорокін, А. С. Супрун та ін. Теорія прецедентності стрімко розвивається. У наукових розвідках уживаються різні терміни, пов'язані з прецедентністю: прецедентний текст, прецедентний феномен (Д. Б. Багаєва, В. О. Вуколова, Д. Б. Гудков, Ю. М. Караулов, . В. Захаренко, В. В. Красних, І. К. Кобякова, К. С. Серажим, Г. Г. Слишкін, Р. С. Чорновол-Ткаченко); логоепістема (В. Г. Костомаров, Н. Д. Бурвікова); прецедентний знак (О. В. Найдюк); прецедентний культурний знак (В. О. Лукін); текстова ремінісиениія (А. С. Супрун, Н. О. Ізмайлова, В. А. Просалова); прецедентна текстова ремінісценція (Ю. С. Прохоров); облігаторні тексти (С. М. Верещагін, В. Г. Костомаров); прецедентна одиниия, прецедентема (Н. А. Голубєва). А. А. Адзінова використовує термін прецедентизм: «Прецедентизми це одиниці мови, що містять прецедентність, джерелами якої є різні типи відтворюваних / стійких у комунікації соціокультурних значущих імен і висловів» $[1,6]$ В. Г. Костомаров i Н. Д. Бурвікова, досліджуючи, як тексти стають прецедентними, аналізують поняття пре- цеедентне висловлювання. Прецедентний феномен і преиедентну ситуацію досліджує В. В. Красних. Прецедентним іменам присвячені численні праці Д. Б. Гудкова.

Теоретичною базою дослідження послужили праці в галузі психолінгвістики (Л. С. Виготський, О. О. Залевська, І. А. Зимня, В. В. Красних та ін.), когнітивної семантики (З. Д. Попова, Й. А. Стернін, О. С. Кубрякова, Ю. М. Караулов та ін.), праці, присвячені вивченню специфіки власних імен (А. В. Суперанська, О. Ссперсен, В. Д. Бондалетов, О. Ю. Карпенко та ін.), дослідження прецедентних феноменів і прецедентних імен (Д. В. Багаєва, Є. М. Верещагін, Д. Б. Гудков, I. В. Захаренко, І. П. Зирянов, Ю. М. Караулов, В. Г. Костомаров, В. В. Красних, О. О. Наумова, О. А. Нахімова, I. В. Привалова, Г. Г. Слишкін, А. С. Супрун та ін.), наукові розвідки в галузі метафорології (Н. Д. Арутюнова, А. М. Баранов, М. Блек, Е. В. Будаєв, М. Джонсон, Дж. Лакофф, В. П. Москвін, В. В. Петров, Є. Є. Юрков), психолінгвістична теорія слова і теорія ментального лексикону як функціональної динамічної системи (О. О. Залевська).

Мета. Дослідити статус і особливості функціонування прецедентних імен в індивідуальному лексиконі білінгвальної особистості шляхом комплексного аналізу даних, отриманих під час вільного асоціативного експерименту.

Матеріали й методи. Матеріалом дослідження стали результати низки вільних асоціативних експериментів, у яких взяли участь природні і штучні білінгви з різних регіонів України. Вибір асоціативних методик зумовлений тим, що специфіка об'єкту дослідження потребує безпосереднього звернення до представника лінгвокультурної спільноти, який володіє набором знань і уявлень і готовий реагувати на представлені слова-стимули. Оскільки дослідження особливостей функціонування прецедентних феноменів в індивідуальному лексиконі пов'язане з вивченням питань когніції, з аналізом зв'язку між позамовною дійсністю, ії ментальною репрезентацією та мовним вираженням, доцільно використовувати комплексний підхід із поєднанням принципів традиційної лінгвістики, лінгвокультурології, когнітивної лінгвістики та психолінгвістики. Використовувалися комплексний теоретичний аналіз, різні види лінгвістичного асоціативного експерименту, психолінгвокультурологічний аналіз і метод кількісної обробки даних.

Результати та їх обговорення. Не зважаючи на різні підходи до феномену прецедентності, очевидно, що в 
усіх випадках йдеться про апеляцію до культурної пам'яті соціуму: кожна окрема мовна особистість, будучи індивідуумом зі своєю свідомістю, пам'яттю, лексиконом, є членом певного соціуму (сімейного, конфесійного, професійного тощо) і має спільні знання, уявлення, ціннісні орієнтації та засоби їх семіотизації $з$ іншими членами цього соціуму; членом лінгво-культурної спільноти, який має певний спільний для всіх членів цієї спільноти набір «культурних предметів» і їхніх символів; представником людства, який має спільні для всіх людей знання й уявлення. Основними компонентами загального для членів лінгвокультурної спільноти ядра знань і уявлень сучасною лінгвістикою визнаються прецедентні феномени. Маємо звернуту увагу на проблему визначення прецедентності. Так, на думку В. В. Красних, прецедентні феномени - це: 1) феномени добре відомі всім представникам національнолінгвокультурної спільноти (мають надособистісний характер); 2) актуальні в когнітивному (пізнавальному й емоційному) плані феномени; 3) феномени, апеляція до яких постійно поновлюється в мові представників національно-лінгвокультурної спільноти $[5,58]$. Однак, теза про те, що прецедентними є феномени, відомі всім без винятку представникам національно-лінгвокультурної спільноти, досить дискусійна: інтелектуальний і культурний рівень мовців, сфери їхніх інтересів $є$ різними, а, отже, критерій загальновідомості при виявленні прецедентних феноменів може викликати сумніви. Д. Б. Гудков прецедентними феноменами вважає одиниці, знайомі більшості лінгвокультурної спільноти, які зберігаються в колективній пам'яті цієї спільноти й регулярно актуалізуються в мовленні [2]. Результати асоціативних експериментів дозволяють сказати, що при визначення прецедентності одиниці краще використовувати вираз «значна частина» лінгвокультурної спільноти, замість узагальнюючих «всі» чи «більшість», оскільки не всі без винятку інформанти реагують на стимули асоціативними реакціями прецедентного типу й не всі 3 тих, хто дає прецедентну реакцію, точно знають характеристики тієї чи іншої прецедентної одиниці. Прецедентним може бути текст, ім'я, висловлювання будь-якої протяжності (від слова чи афоризму до епосу). Прецедентність є одиницею «осмислення людських життєвих цінностей крізь призму мови за допомогою культурної пам'яті», тобто розглядається як компонент мовної свідомості соціуму [4, 73]. Показником прецедентності феномену є часті відсилання до тексту в процесі побудови нових феноменів у вигляді ремінісценцій [7, 28]. Отримання і збереження феноменом статусу прецедентності зумовлене тим, наскільки він відповідає запитам життєвої ідеології конкретного соціуму.

Отже, прецедентними феноменами будемо вважати добре відомі (хоча поняття «добре відомі» теж може викликати дискусії: що вважати критеріями такого знання? те, що інформант знає це ім'я, чи те, що він може навести цитату з твору чи зазначити якісь характеристики феномену?) значній частині представників лінгвокультурної спільноти, актуальні в когнітивному й пізнавальному плані вербальні або вербалізовані феномени, звернення до яких простежується в мові певної лінгвокультурної спільноти і які входять у когнітивну базу. До таких феноменів належать прецедентні тексти, прецедентні ситуації, прецедентні висловлювання та прецедентні імена.

Прецедентні імена, з одного боку, є частиною когнітивної бази носія мови, а 3 іншого - належать до класу власних імен. Вони фіксують певні аспекти національної картини світу і пов'язані 3 процесами номінації. Під прецедентним іменем розуміють індивідуальне ім'я, пов'язане: a) iз широко відомим текстом, який належить, як правило, до прецедентних; б) із ситуацією, широко відомою носіям мови, яка виступає як прецедентна [2, 106]. Використання терміну прецедентне ім'я при описі процесів номінації дозволяс дослідити причини набуття власним іменем ознак прецедентності. На специфіку функціонування прецедентних імен впливають їхні структурні особливості. В.В. Красних зазначає, що прецедентне ім'я може функціонувати або як власне ім'я, вказуючи безпосередньо на денотат (у цьому випадку диференційні ознаки прецедентного імені виявляються не релевантними), або як прецедентні імена (тобто вживатися як «складний знак», що має окрім простого набору значень деякий інваріант сприйняття «предмету», який стоїть за іменем). У цьому випадку має місце апеляція до диференційних ознак прецедентного імені, які становлять ядро індивідуального варіанту прецедентного імені $[6,202]$. За концепцією Д. Б. Гудкова, прецедентні імена поділяються на ті, що функціонують денотативно (екстенсіонально), тобто іменують предмет, вказуючи безпосередньо на денотат, i ті, які функціонують конотативно (інтенсіонально), тобто використовуються для характеристики об'єкту. Денотатом прецедентного імені визнається уявлення про іменований ним «культурний предмет» [2].

При виборі методів дослідження ми спиралися на теорію єдиної інформаційної бази та концепції лексикону людини як динамічної, функціональної системи, розроблену О.О.Залевською, за якою слово - одиниця лексикону - розглядається як засіб доступу до єдиної інформаційної бази людини, де зберігається сукупність певним чином емоційно забарвлених і визначених системою норм і оцінок тієї спільноти, до якої належить мовна особистість, мовних і енциклопедичних знань. Слово при ідентифікації включається у внутрішній контекст (перцептивний, когнітивний, афективний), який пов'язаний із зовнішнім контекстом (вербальним, ситуативним). При цьому слово як ключова одиниця запускає в дію складну сукупність процесів функціонування індивідуального знання, актуалізує в індивідуальній свідомості певний фрагмент досвіду. Досвід актуалізується у вигляді цілісного чуттєво-когнітивно-афективного утворення, яке складається з ознак і ознак ознак. При цьому враховуються різноманітні знання людини [3]. Можна припустити, що прецедентне ім'я при його використанні й сприйнятті мовцями також актуалізує певний специфічний «контекст» пов'язаних із ним знань, що має проявитися під час експериментального дослідження. 3 метою перевірки цього припущення був проведений вільний асоціативний експеримент. Інформантам пропонувалося письмово відреагувати на запропоновані слова-стимули. До участі в експерименті було залучено 120 інформантів - природних або штучних білінгвів різного віку, статі, професій, які добре володіють щонайменше двома мовами. Інформанти не обмежувалися ні у виборі реакцій, ні у їх кількості; вони могли записа- 
ти одне слово, словосполучення або ціле речення будьякою відомою їм мовою (загальна кількість отриманих асоціативних реакцій - 1698). Вільний асоціативний експеримент мав на меті виявити, які образи-уявлення стоять за прецедентними іменами в свідомості людей, які знають декілька мов.

Прецедентність, як лінгвістичне явище, зумовлена національними, соціальними, історичними й іншими чинниками, тому може бути представленою на різних рівнях: національному, соціумному, універсальному, індивідуальному й у різних сферах функціонування мови. В індивідуальному когнітивному просторі мовної особистості ім'я може бути пов'язаним із двома денотатами: особистісними уявленням й загальнонаціональним інваріантом, який зберігається в когнітивній базі лінгвокультурної спільноти в максимально редукованому вигляді. Саме наявність такого інваріанта $\epsilon$ доказом прецедентності імені. За кожним прецедентним феноменом стоїть своя унікальна система асоціацій, яка відображається у свідомості носіїв мови. Саме це включення в асоціативні зв'язки 3 іншими мовними концептами зумовлює регулярну актуалізацію прецедентних феноменів. При цьому асоціативні зв'язки розглядаються як аспекти прецедентності.

Отримані асоціативні реакції були класифіковані відповідно до базових стратегій ідентифікації: образи/уявлення, які базуються на інваріанті сприйняття прецедентного імені/прецедентної ситуації, реакції, зумовлені формою слова-стимулу, реакції, що апелюють до індивідуального досвіду тощо. Загальний аналіз результатів експериментів свідчить, що прецедентна база білінгвів має «дифузний» характер: у ній можуть бути відсутніми інваріанти сприйняття деяких політичних діячів i літературних персонажів (напр., наявність/відсутність реакцій Гаррі Поттер, Рейган, Карл Маркс, Хрущзов, Брежнєв на одні і ті самі слова-стимули залежить від віку інформантів) та з'являтися нові імена, на які орієнтується мовець (напр., Трамn) тощо.

Прецедентне ім'я має експресивну, символічну, конотативну функції та здатне передавати культурну інформацію. Прецедентні імена як одиниці мови й мовлення виступають репрезентантами прецедентних концептів ментально-вербальних одиниць, які використовуються для презентації, категоризації, концептуалізації й оцінки дійсності при формуванні картини світу. Серед прецедентних імен найчастіше виділяють антропоніми, хрематоніми (назви продуктів матеріального і духовного життя людини, напр., назви книжок, фільмів, пісень, музичних груп) і хрононіми (назви подій, явищ), однак цими одиницями прецедентні імена на вичерпуються.

В індивідуальному когнітивному просторі мовної особистості ім'я може бути пов'язане з двома денотатами: особистим уявленням і загальноціональним інваріантом, що зберігається в когнітивній базі лінгвокультурної спільноти в максимально зредукованому вигляді. Наявність такого інваріанта вважається доказом прецедентності імені. У матеріалах асоціативного експерименту представлені так звані автопрецееденти - «відображення в свідомості індивіда деяких феноменів навколишнього світу, які мають особливе пізнавальне, емоційне, аксіологічне значення для певної особистості, пов'язані 3 особливими індивідуальними уявленнями, включеними в неповторні асоціативні ряди» $[2,103]$ : напр., асоці- ативна реакція Wolfenstein на стимул НІМЕЧЧИНА; Юбicoфm, Nikita Mikhailenkoi на стимул ФРАНЦІЯ. Соціумно-прецедентні феномени відомі будь-якому середньому представнику соціуму і входять до колективного когнітивного простору (реакція прецедентного типу Різдво на стимул ЗИМА). Національнопрецедентні феномени відомі будь-якому пересічному представнику лінгвокультурної спільноти і входять до когнітивної бази цієї спільноти. Як правило, увага дослідників зосереджується саме на національнопрецедентних феноменах і саме їх часто називають прецедентними феноменами. Універсально-прецедентні феномени відомі усім людям і входять до універсального когнітивного простору людства (напр., Велика Китайська стіна, Джекі Чан на стимул КИТАЙ, Ейфелева вежа, Нотердам де Парі на стимул ФРАНЦІЯ).

Як відомо, в ономастиці виділяють різні типи онімів: антропоніми, міфоніми, топоніми, астроніми, назви подій тощо. Провідне місце належить прецедентним антропонімам, однак, слід зауважити, що у відповідях респондентів представлені й інші власні назви. Так, у матеріалах експериментів, крім антропонімів, представлені прецедентні імена, які позначають важливі події через вказівку на їхню дату (33-й рік,1 вересня 1939, 1939-1945); прецедентні імена, що позначають ті чи інші події через назву місця, де вони відбулися (Нагасакі, Хіросіма на стимул ЯПОНІЯ); прецедентні імена, які позначають об'єкти бізнесу - компанії, заводи, концерни, банки тощо (Силіконова долина, Googl, Apple, Голівуд, Емпайр Стейт Білдінг на стимул США); прецедентні імена, які позначають широко відомі географічні об'єкти (Ватикан, Венеція на стимул ІТАЛІЯ); прецедентні назви країн, які можуть нагадувати про особливості їхнього історичного досвіду (Гондурас на стимул БІДНІСТЬ); прецедентні імена, які йдуть від назв кораблів (найбільш відомим і часто повторюваним таким іменем $\epsilon$ «Титанік» - назва лайнера, який затонув у результаті зіткнення 3 величезним айсбергом, зараз використовується мовцями для образного позначення будь-яких катастроф чи загрозливих ситуацій; цікавим є асоціативний ряд на стимул КІНО: Бред Пітm, Леонардо ді Kanpio, «Титанік», «Адмірал Нахімов» (назва іншого пасажирського судна, яке також затонуло в результаті кораблетрощі в кінці XX ст., стало прецедентним іменем катастрофи, як і Титанік).

Як свідчить експериментальний матеріал, найбільш частотною групою прецедентних імен $€$ прецедентні антропоніми (практично на кожне слово-стимул зафіксовані реакції-антропоніми, на деякі стимули - по декілька антропонімів), пор.: США - Трамп, Обама, Бред Пітт, Анджеліна Джолі, Джордж Буш, Білл Гейтс, Стів Джобс; ІТАЛІЯ - Муссоліні, Adriano Celentano, РУМУНІЯ - Дракула, Чаушеско тощо. Деякі прецедентні імена-антропоніми стають стимулом для ланцюжка прецедентних онімних реакцій, напр.: ОСТАП БЕНДЕР - Бендера, Бандера, Бандерас, А. Миронов.

На другому місці за частотністю знаходяться прецедентні топоніми. Прецедентними топонімами на позначення великої, багатої й авторитетної країни можна вважати частотні асоціативні реакції США, Франиія, Німеччина, які часто даються на стимул БАГАТИЙ. На позначення юридичного договору, який неоднозначно сприймається суспільством, раніше використовувався 
топонім Брест, а зараз деякі інформанти наводять топонім Мінськ. Позначення важливої політичної події за допомогою вказівки на вулицю, площу, будівлю, де воно відбулося можливе, напр., за допомогою одиниць Майдан, Банкова, Білий Дім. Функціонування і сприйняття прецедентних імен тісно пов'язано з особливостями національної культури, традиціями й ментальністю національно-мовного колективу (такими є, напр., асоціативні реакції представників різних лінгвокультурних спільнот на стимул Майдан).

При відповіді на стимули не обмежувалася мова реакції. Білінгви в більшості випадків відповідали українською мовою (мовою запропонованої анкети). Однак, близько $10 \%$ анкет заповнені переважно російською, є деякі анкети, заповнені іншими мовами (польською, англійською, німецькою: інформанти перекладали стимул рідною мовою і давали реакції вже рідною мовою). В інших анкетах наводяться цитати з літературних творів, текстів пісень, гасла, рекламні слогани російською мовою чи іншими мовами (мовою джерела прецедентного імені). Серед найбільш активних понятійних сферджерел прецедентних імен можна виділити політику, літературу, театр і кіно, спорт, музику, мистецтво, науку та ін. Джерела прецедентності можуть бути вітчизняними і закордонними, реальними або належати до сфери літератури чи мистецтва, бути сучасними чи йти з інших історичних періодів. Прецедентні імена в матеріалах вільного асоціативного експерименту могли бути представлені у структурно трансформованому вигляді і без змін форми, використовуватися ізольовано й у складі реакції-словосполучення чи речення. Заслуговує на увагу спосіб зазначення інформантами джерела прецедентності (на стимул наводилися назва твору, його автор, історичний період, атрибут прецедентного імені тощо). Іноді інформантами використовувалися графічні маркери прецедентності імені (лапки, перехід на графіку іншої мови, інші графічні засоби).

Висновки. Проведене дослідження свідчить, що прецедентні імена - це важлива частина національної мовної картини світу, важливий засіб пізнання, концептуалізації й оцінки дійсності. Вони відображають систему цінностей лінгвокультурної спільноти. Прецедентні антропоніми, топоніми, ситуації є елементами культурного простору. Найчастіше прецедентними стають власні імена видатних особистостей (відомих історичних особистостей, політиків, державних діячів, діячів культури, мистецтва й науки) і топоніми. Аналіз асоціативних реакцій дозволяе говорити про прояв номінативної, когнітивної, оцінної, прагматичної та комунікативної функцій прецедентних імен. Для дослідження статусу прецедентних імен в індивідуальному лексиконі особистості, вивчення ступеню знання прецедентних феноменів доцільно використовувати різні види асоціативного експерименту, метод дефініцій та інші сучасні методи і прийоми психолінгвістики, когнітивної лінгвістики, лінгвокультурології. Прецедентні феномени в когнітивній базі зберігаються у вигляді інваріанта сприйняття. Поява варіантів сприйняття прецедентних імен може пояснюватися динамікою прецедентно бази: у різних поколінь - різний досвід, різні погляди й уявлення про реальність, отже, можуть з'являтися «нові» прецеденти, a «традиційні» мати різний рівень актуалізації в різних вікових групах. Використання сучасних методик дає можливість дослідити групові, регіональні, національні й інтернаціональні прецедентні феномени. Дослідження особливостей зберігання і функціонування прецедентних імен в індивідуальному лексиконі двомовної особистості дозволяє робити подальші кроки в розвитку теорії прецедентності, теорії організації та функціонування індивідуального знання мовної особистості, організації ментально-вербального лексикону.

\section{ЛIТЕРАТУРА}

1. Адзинова А. А. Явление прецедентности в заглавиях креолизированных текстов (на материале глянцевых журналов): автореф. дисс. канд. филол. наук. - Майкоп, 2007. - 23 с.

2. Гудков Д. Б. Теория и практика межкультурной коммуникации. - М., 2003. $-288 \mathrm{c}$.

3. Залевская А. А. Введение в психолингвистику: учебник. 2-е изд. испр. и доп. - М.: РГГУ, 2007. - 560 с.

4. Костомаров В. Г. Как тексты становятся прецедентными // Русский язык за рубежом. - 1994. - № 1. - С. 73-76.

5. Красных В.В. Этнопсихолингвистика и лингвокультурология. - М., 2002.

6. Красных В.В. «Свой» среди «чужих»: миф или реальность? M, 2003. -375 c.

7. Слышкин Г. Г. От текста к символу: лингвокультурные концепты прецедентных текстов в сознании и дискурсе. - М., 2000. $-128 \mathrm{c}$.

\section{REFERENCES}

1. Adzinova A.A. The phenomenon of precedent in the titles of creolized texts (based on the language of glossy magazines): Dissertation abstract for the Candidate of Philology degree. - Maikop, 2007. - 23 p.

2. Gudkov D. B. Theory and practice of intercultural communication. - Moscow, 2003. - 288 p.

3. Zalevskaya A. A. Introduction into psycholinguistics. The $2^{\text {nd }}$ edition. - Moscow: Russian State University of Humanities, 2007. -560 p.

4. Kostomarov V.G. How do texts become precedent // Russian language abroad. - 1994. - \# 1. - p. 73-76.

5. Krasnykh V.V. Ethnopsycholinguistics and lingvoculturology. Moscow, 2002.

6. Krasnykh V.V. "At Home Among Strangers": a myth or a reality? - Moscow: Gnosis, 2003. - 375 p.

7. Slyshkin G.G. From text to symbol: Linguistic culture concepts of precedent in consciousness and discourse.-Moscow, 2000.-128 p.

\section{Precedent names in the individual lexicon of the bilingual personality}

\section{O. A. Gapchenko}

Abstract. The article studies the status of precedent phenomena in a bilingual individual lexicon. Precedent names are considered both as linguistic signs and cognitive base elements. There analyzed the factors which determine the storage and functioning specifics of precedent type cases in the structures of bilingual individual lexicon. The facts of impact of individual natural and combined bilingualism on these processes are also viewed.

Keywords: linguistic personality, precedent phenomenon, individual lexicon, ethnolinguistic and cultural consciousness. 